\title{
Broodstock Age as a Determinant of Embryonic Development and Growth of Rohu (Labeo rohita) under Captive Conditions
}

\author{
Deepti Negi, Garima Singh, Bonika Pant* and R.N. Ram
}

\author{
Department of Fisheries Resource Management, College of Fisheries, GBPUA \& T, \\ Pantnagar, U.S. Nagar - 263145, India \\ *Corresponding author
}

\begin{tabular}{|c|c|}
\hline \multicolumn{2}{|r|}{ A B S T R A C T } \\
\hline Keywords & \multirow{3}{*}{$\begin{array}{l}\text { The present study is undertaken to observe different stages of embryonic development of } \\
\text { an Indian major carp, Labeo rohita of two different age groups }(+2 \text { and }+3) \text {, kept under } \\
\text { culture and hatchery conditions. The studies of embryonic and larval development provide } \\
\text { the essential information regarding the early life history of the target species kept under } \\
\text { experimentation. The main aim of this study is to provide information about the } \\
\text { comparison of embryonic development of the same species with two different brooder age } \\
\text { groups. Egg size, morula formation, organogenesis, yolk absorption rate, larval size at } \\
\text { hatching, and onset of feeding were examined under this experiment. The results suggested } \\
\text { that the embryos of the fishes of }+3 \text { age group showed better and faster growth as well as } \\
\text { development than the embryos of fishes of }+2 \text { year age group. }\end{array}$} \\
\hline Article Info & \\
\hline $\begin{array}{l}\text { Accepted: } \\
\text { 20 November } 2018 \\
\text { Available Online: } \\
\text { 10 December } 2018\end{array}$ & \\
\hline
\end{tabular}

\section{Introduction}

Existence of fish species on earth have been witnessed for more than 450 million years. According to Fish Base details in 2014, out of 32,800 species of fish $58 \%$ are saltwater, $41 \%$ are freshwater and remaining $1 \%$ are anadromous fishes. Fish contribution in our daily food is in the increasing order, when compared with meat from terrestrial farm animals. For humans, fish is the major source of protein, which provides significant portion of nutrient to a large proportion of people (Ochokwu et al., 2014). Carps are the backbone of Indian freshwater aquaculture, constituting $95 \%$ of the total freshwater fish production (FAO, 2014). Since the freshwater ecosystems of the Indian subcontinent are inhabited by a vast diversity of carps, it is considered as a 'carp country'. There are about 2,070 carp species available in Indian waters, out of which the Rohu fish alone contributes $35 \%$ of the total Indian major carp fish production (Mohanta et al., 2008). Its high consumer preference along with its high growth rate has made it the most sought species cultured in India.

Rohu is found in the rivers, ponds and lakes of India and neighbouring countries (Talwar and Jhingran, 1991). The body is elongated with a slightly depressed snout. The lips are thick and fringed. The body is black brownish with silver color on the sides and beneath (Rahman, 
2005). L. rohita is omnivorous in nature and tends to change its feeding habit during its entire life cycle. Rohu prefers zooplanktons mainly rotifers and cladocerans, in the early fingerling stage while in the adult stage, it prefers algae and submerged vegetation (Das and Moitra, 1955). Among all the Indian major carps, Labeo rohita (Hamilton, 1822) is probably the most sought and also most intensively cultured species (Jhingran and Pullin, 1985). Maturity is attained towards the end of second year (Alikunhi, 1957) and spawning occurs once a year (Khan, 1972). Breeding of Rohu does not occur in lentic conditions, hence induced breeding is done to successfully breed it under captive conditions. The fertilized eggs of Rohu are demersal, round, transparent with a reddish tinge. Size of fully fertilized eggs is $5 \mathrm{~mm}$ in diameter (Mazumdar, 1957). Research studies on factors like growth, age and maturity of commercial fishes like Rohu helps in depicting and recognizing various geographic areas that portrays individual stock (Pawson and Jennings, 1996). With this aim in mind, the following experiment was setup.

The age of parents can affect egg quality, sperm fertility and larval rearing, hence the parental attributes and reproductive properties are crucial factors deciding the progeny performance. Studies claim that the age of brooders is one of the major factors that determine the quality of egg and sperm and therefore the embryonic development of the progeny.To satisfy the increasing demand of high quality fish and fish products, the aim of present study is to report the effect of embryonic brooder age of farm raised Labeo rohita on the embryonic development under the captive conditions.

\section{Materials and Methods}

\section{Experimental fish}

The experiment was conducted on the brooders of +2 and +3 year age groups. Fishes were collected from the age wise separated brood stock ponds during monsoon season in 2017. The experiment was conducted in the Instructional Fish Farm of College of Fisheries, Pantnagar. Fully matured male and female of were selected and selection was done on the basis of external secondary sexual characters.

\section{Selection and handling of brood stock}

Mature healthy brooders were selected according to the sexual dimorphism for the breeding purpose for +2 year age group males of 1.2-1.4 kg and females of 1.4-1.6 kgwere taken and for +3 year age group males of 1.6$1.8 \mathrm{~kg}$ and females of $1.8-2.0 \mathrm{~kg}$ were selected. They were examined for any disease and then transferred to the cemented holding tanks of the hatchery. The brooders of +2 year age groups were transferred to Tank No.01 and brooders with +3 year age group were transferred to Tank No.02.

\section{Hormone}

GonoPro-FH was used as the hormone for induced breeding of fish. It is available in liquid form in bottle and it is a salmon-GnRHanalog. The amount recommended by the manufacturers for successful induced spawning of carps is $0.4 \mathrm{ml} / \mathrm{kg}$. In females, Gonopro-FH was injected at the base of the dorsal fin, intramuscularly, in the the selected brooders.

Calculation of hormonal quantity to be injected

Quantity to be injected $(\mathrm{ml})=$ Weight of brood fish $(\mathrm{kg}) \mathrm{x}$ dosage of GonoPro-FH (ml)

The fishes were held firmly and weighed cautiously. Then a calculated amount of single dose as prescribed by manufacturer of GonoPro-FH injection to female was given intramuscularly. The needle was inserted 
under the scale with hypodermic $2 \mathrm{ml}$ syringe through to a depth of about $1.5 \mathrm{~cm}$ and the fluid was injected slowly.

\section{Time of injection}

The dose of GonoPro-FH injection was administered in the evening around at 5 P.M. as the time of injection depends on the water temperature. The climate of Pantnagar is hot and humid hence evening is the best time for injection due to optimal temperature during this season.

\section{Handling and transfer of brooders}

After giving the adequate dosage, brooder fishes in the ratio of 2:1 (male: female) were immediately transferred to breeding pool in plastic bucket. Each plastic bucket carried 50 litres of well-oxygenated water to reduce the stress. Fishes with both of the age groups were transferred to separate tanks. Acclimatization was maintained to avoid fish mortality. The place of injection of hormone was in close vicinity to Chinese hatchery hence no anaesthesia was given during transfer of brood fishes.

\section{Breeding and spawning}

Right after injecting the single dose of GonoPro FH hormone to both males and females of rohu, they were put in the breeding tanks of the institutional chinese hatchery with the ratio of 2:1 (male: female). Showering and water jets were provided in both the tanks so as to create circular water motion and soon after about 8 hours of showering they showed sexual play. Males started chasing females and female laid eggs. Spawning took place after 16 hours of injection at temperature $26-28^{\circ} \mathrm{C}$. In general, during breeding, hatching, embryonic and larval development, an important role is played by the environmental and physicochemical conditions of the water. Parameters of water play a pivotal role in the metabolism and survival of fish eggs and hence water quality parameters were observed during the development and were maintained properly.

\section{Collection of eggs}

The unfertilized and fertilized eggs were differentiated. The opaque were identified as unfertilized eggs while the transparent were taken as fertilized ones. Few eggs were collected and were washed with the solution of potassium permanganate for disinfection. Selected eggs of both the age groups were kept separately in two disinfected plastic tubs of different color in order to avoid any confusion further throughout the experiment. The eggs were kept in the room temperature.

\section{Observations}

The embryonic development was keenly observed under a microscope (Motic Digital) which was connected to a computer. Pictures of different stages were taken. Eggs were examined under the microscope in every two hours from $6^{\text {th }}$ hour to $18^{\text {th }}$ hour and then in every 6-8 hours interval for the rest of the experiment. Eggs were placed on the slide with spatula and excess water was removed for better quality images.

\section{Results and Discussion}

The length and weight of +2 and +3 year old brooders is given in Table 1 and 2 respectively. Other than the physico chemical parameters of the water body, the age group also plays an important role in the embryonic development of fish. Embryonic development of rohu of +2 year age and +3 year age group was observed. Soon after fertilization, early indication of the embryo was seen after $4 \mathrm{hrs}$. The development of blastodisc, was seen earlier in +3 age group ( 6 hrs) than +2 year. 
Differentiation of the head and tail regions was found to be faster in the +3 age group (14 hrs). The embryos were comma shaped in both groups and +3 year broodstocks embryos were slightly more elongated. Twitching movement in the embryo started after $16 \mathrm{hrs}$ of fertilization and it was observed that embryos of +3 year group were showing more active twitching movement. Hatching occurred after 18 hrs of fertilization in both groups.

Newly hatched larvae were transparent and slender in shape. It was observed that embryos of +2 year group had prominent and large yolk mass with a bulbous anterior portion as compared to +3 year group hatchlings. Brain development was noticed after $26 \mathrm{hrs}$ followed by the development of the mouth and eyes. Heart was seen to be situated anterior to this yolk mass.
Chromatophores were seen in the eyes 16-18 hrs after hatching (36-38 hrs), making them look black. Fewer chromatophores were observed on the dorsal margin of the yolk sac 22- $24 \mathrm{hrs}$ after hatching. The pectoral fin was conspicuous after 36- $38 \mathrm{hrs}$ of hatching (54$56 \mathrm{hrs}$ ). At about $62 \mathrm{hrs}$, the yolk mass was seen to reduce and this reduction was seen faster in the fish of the +3 age group. After 62- $66 \mathrm{hrs,} \mathrm{chromatophores} \mathrm{were} \mathrm{seen} \mathrm{all} \mathrm{over}$ the head, fins and body of the hatchlings. The average size of hatchlings ranged from 6.8 $\mathrm{mm}$ to $7.0 \mathrm{~mm}$ but hatchlings of +3 year broodstock were longer than +2 year. Yolk absorption in both the groups was observed after $72 \mathrm{hrs}$ of hatching. At 80 hours the larvae were well developed with distinct fins, complete open mouth, alimentary canal and branchial system and active feeding was observed.

Table.1 Weight and length of brooder males and females of +2 age group

\begin{tabular}{|c|c|c|c|c|}
\hline \multirow{2}{*}{ S.No. } & \multicolumn{2}{|c|}{ ROHU MALE } & \multicolumn{2}{c|}{ ROHU FEMALE } \\
\cline { 2 - 5 } & Weight $(\mathrm{kg})$ & Length $(\mathrm{cm})$ & Weight $(\mathrm{kg})$ & Length $(\mathrm{cm})$ \\
\hline $\mathbf{1}$ & 1.2 & 41.5 & 1.6 & 46.5 \\
\hline $\mathbf{2}$ & 1.4 & 44.5 & 1.4 & 43.0 \\
\hline $\mathbf{3}$ & 1.4 & 45.0 & 1.6 & 47.0 \\
\hline $\mathbf{4}$ & 1.3 & 42.0 & 1.5 & 44.5 \\
\hline $\mathbf{5}$ & 1.4 & 44.0 & 1.6 & 46.0 \\
\hline $\mathbf{6}$ & 1.3 & 43.0 & 1.4 & 42.5 \\
\hline $\mathbf{7}$ & 1.4 & 44.0 & 1.6 & 46.0 \\
\hline Mean & 1.34 & 43.42 & 1.53 & 45.07 \\
\hline
\end{tabular}

Table. 2 Weight and length of brooder males and females of +3 age group

\begin{tabular}{|c|c|c|c|c|}
\hline & \multicolumn{2}{|c|}{ ROHU MALE } & \multicolumn{2}{c|}{ ROHU FEMALE } \\
\cline { 2 - 5 } S.No. & Weight $(\mathrm{kg})$ & Length $(\mathrm{cm})$ & Weight $(\mathrm{kg})$ & Length $(\mathrm{cm})$ \\
\hline $\mathbf{1}$ & 1.7 & 48.0 & 2.0 & 51.0 \\
\hline $\mathbf{2}$ & 1.6 & 47.5 & 2.2 & 53.0 \\
\hline $\mathbf{3}$ & 1.7 & 47.5 & 1.9 & 50.0 \\
\hline $\mathbf{4}$ & 1.7 & 48.0 & 1.8 & 49.0 \\
\hline $\mathbf{5}$ & 1.6 & 47.0 & 1.9 & 50.5 \\
\hline $\mathbf{6}$ & 1.6 & 46.0 & 1.8 & 48.0 \\
\hline $\mathbf{7}$ & 1.7 & 49.0 & 2.0 & 51.5 \\
\hline Mean & 1.66 & 47.57 & 1.94 & 50.43 \\
\hline
\end{tabular}


Plate.1 Development of Labeo rohita eggs incubated at room temperature in the laboratory conditions upto 80 hours

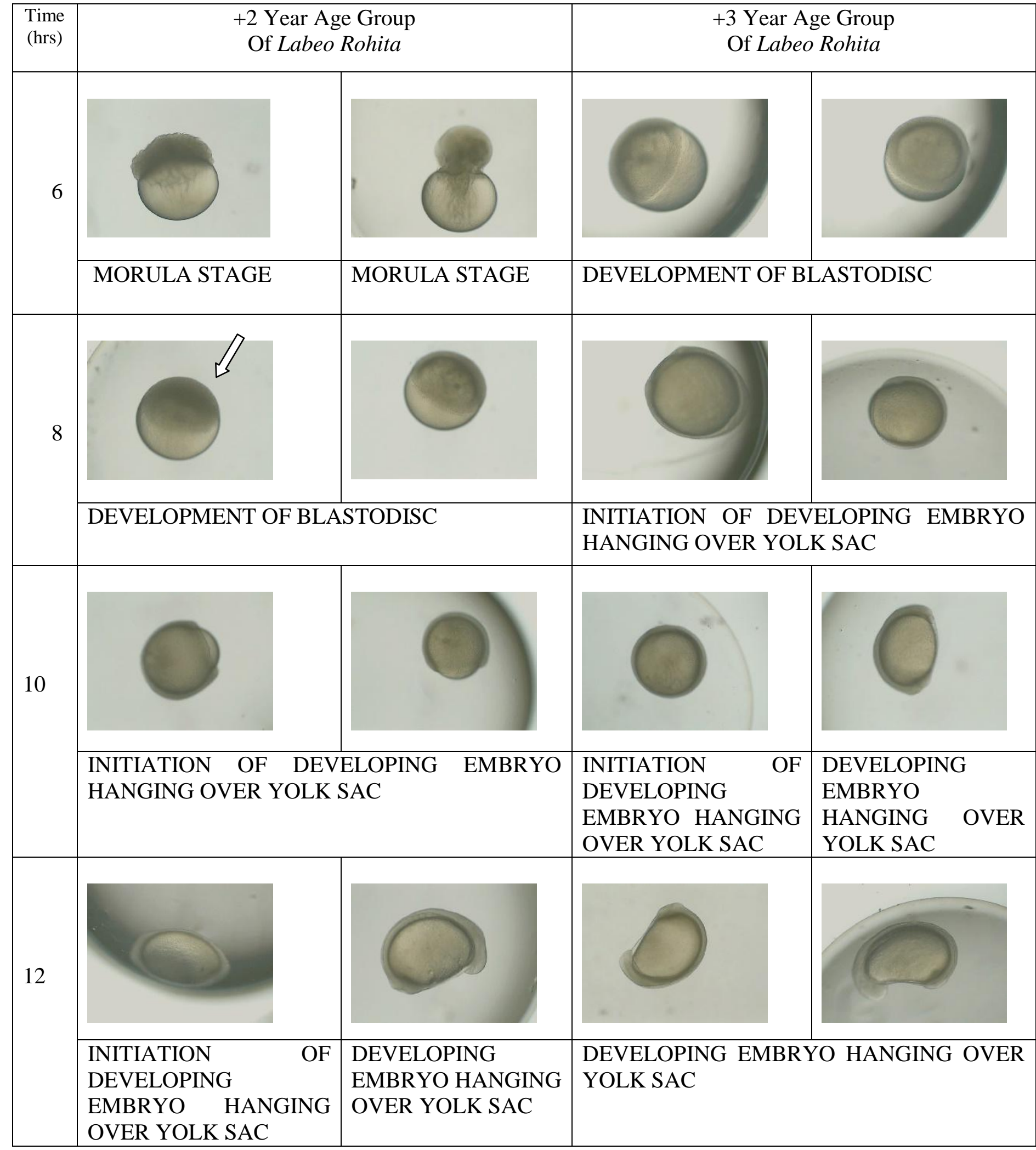




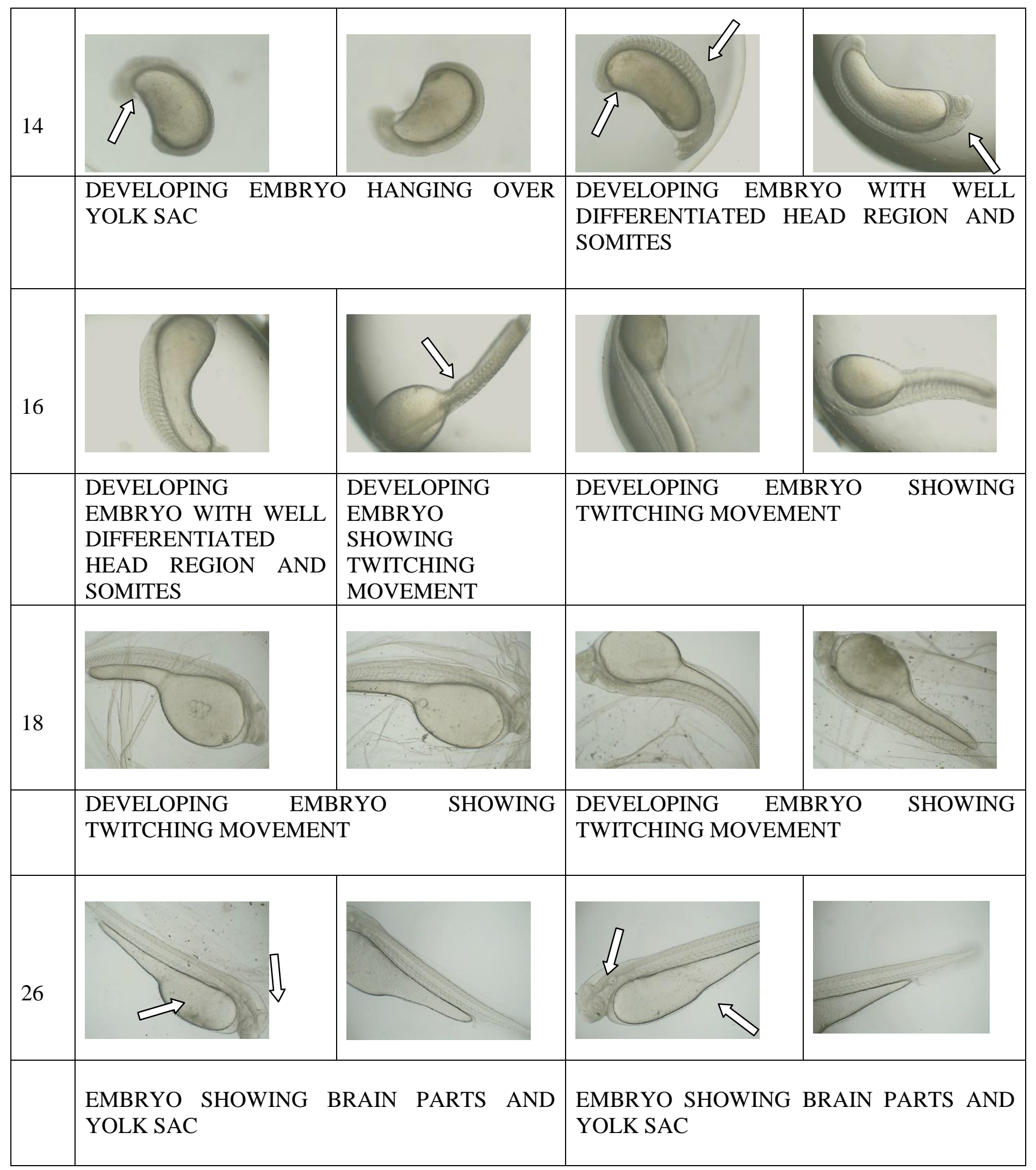




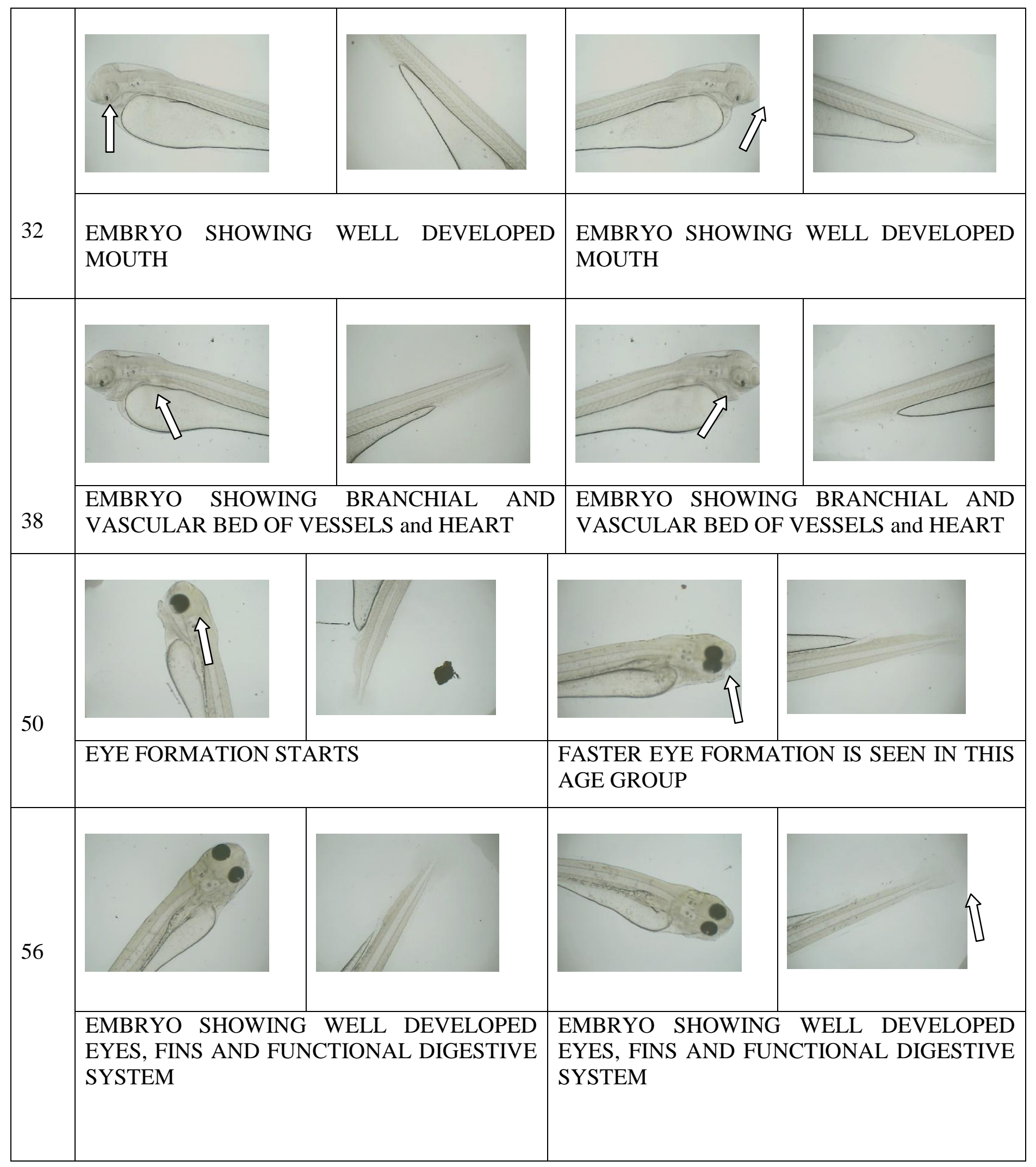




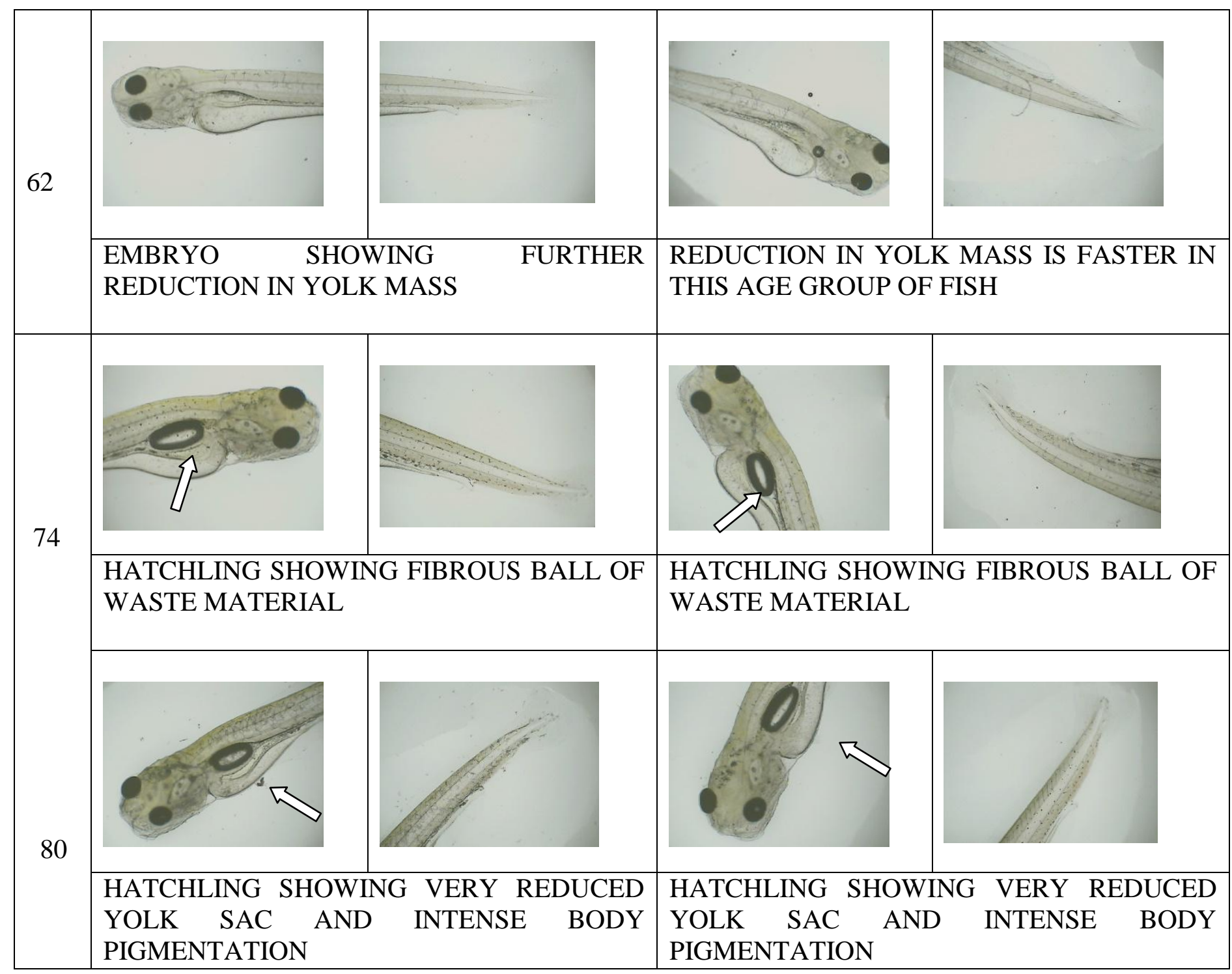

It has been proved by various researches that the reproductive success relies on the quality of both male and female gametes, which in turn is an age dependent factor. Any investigation of effect of brooder's age on reproductive efficiency and survival rate of obtained larvae involves consideration of gamete quality, since the healthy larvae are always obtained from healthy gametes (Kjorsvik et al., 1990). Present study showed that age of the brooders has a huge impact on the reproductive success, in terms of fertilization, egg quality and embryonic development.
According to our results, +3 year old females produced eggs with more diameters $(3.26 \mathrm{~mm})$ compared to +2 year old females $(3.19 \mathrm{~mm})$. Many researchers have stated that when brood fish size or age is increased and the egg size is also increased (Bromage and Cumaranatunga, 1988; Bromage et al., 1992). The egg quality and especially egg diameter and weight have positive impact on fertilization rate and improvement of egg incubation as well as progeny performance. Relation of age and size of females with the egg quality has also been demonstrated in studies on fish by (Quintero et al., 2011). It has been seen that older females spawn larger eggs (Brooks et 
al., 1997), showing higher fertilization and hatching rates (Evans et al., 1996; Solemdal et al., 1998; Trippel et al., 1998; Laine and Rajasilta, 1999). A decline in the fertilization and hatchability rates with an increase in the age of the females, similar to that was also reported by (Bromage et al., 1992) and (Brooks et al., 1997). Age-fecundity relationship has also been reported by Rana (1988), Ridha and Cruz (1998) in Tilapia fish stating that the fecundity increased with the age of female brooders.

It has also been noted that with an increasing trend in age, the eggs per spawn increases, while the egg production capacity declines. This is in agreement with similar decrease in egg production capacity with age in $S$. melanotheron (Lowe, 1982). According to (Kjorsvik et al., 2003) the egg size is a determinant of egg quality and it has been seen that the amount of yolk reserves is higher in the eggs from older fish and that the fry is capable to tolerate starvation for a longer period of time.

In our study, the egg numbers per gram were higher in +2 year old females compared to +3 year old individuals. This could be due to the smaller size of eggs in these females than in +3 year old females. In the present study, the +3 year old females had more fecundity and more larvae with higher survival rate compared to +2 year old females. Therefore, this result suggests that egg size have a positive relationship with egg and larval quality during incubation period.

In conclusion the crossing of two different age classes of Labeo rohita to identify the better age with maximum reproductive efficiency suggested that +3 year old brooders of Rohu have more reproductive efficiency, better hatching and larval survival rate, better egg quality and embryonic development hence achieved the maximum reproductive success than +2 year old brooders of Rohu. The embryos of the fishes of the +3 age group showed better as well as faster growth and development than the embryos of fishes of +2 year age group. Results from this study can be useful for broodstock selection in captive reproduction of Labeo rohita as well as for hatchery management. Our findings support the fact that selection of brooders according to age is a crucial determinant in the embryonic development of Labeo rohita as it affected the maturation of the developing embryo in various aspects.

\section{Acknowledgement}

The Authors are thankful to the Dean of the college, staff of the Instructional Fish Farm and the departmental lab for rendering lab facilities to conduct this work.

\section{References}

Alikunhi, K.H. (1957). Fish culture in India. Farming Bull. Indian Counc. Agric. Res. 20. 144 p.

Ayyappan, S. and Jena, J.N. (2001). Sustainable freshwater aquaculture in India. In: T. J. Pandian (ed.), Sustainable Indian Fisheries, National Academy of Agricultural Sciences, New Delhi, India. 83-133.

Bromage, N. R., Jones J., Randall C., Thrush M., Davies B., Springate J., Duston J., and Barker G. (1992). Broodstock management, fecundity, egg quality and the timing of egg production in the rainbow trout, Oncorhynchus mykiss. Aquaculture. 100,141-166.

Bromage, N.R., Cumaranatunga, P.R.T., (1988). Egg production in rainbow trout. In: Muir, J.F., Roberts, R.J., (Eds.), Recent Advances in Aquaculture. Groom Helm Ltd., London. 65-138.

Brooks, S., Tyler C. R. and Sumpter J. P. 
(1997). Egg quality in fish: what makes a good egg? Reviews in Fish Biology and Fisheries. 7, 387-416.

Das, S.M., Moitra, S.K., (1955). Studies on the food of some common fishes of Uttar Pradesh, India. Proc. Natl. Acad. Sci. (B). 25(1-2), 1-6.

Evans R.P., Parrish C.C., Brown J.A. and Davis P.J. (1996). Biochemical composition of eggs from repeat and first time spawning captive Atlantic halibut (Hippoglossus hiypoglossus). Aquaculture. 139, 139-149.

FAO, (2014). The State of World Fisheries and Aquaculture. Food and Agriculture Organization of the United Nations. Rome, Italy, 243 pp.

Geninet, G.T. (2008). Ethiopian Institute of Agricultural Research, National Aquaculture Center, Addis Ababa, Ethiopia

Gopakumar, K., Ayyappan, S., Jena, J.K., Sahoo, S.K., Satapathy, S.K., Sarkar, B.B. and Nayak, P.K. (1999). National Freshwater Aquaculture Development Plan. CIFA, Bhubaneswar, India, 75 pp.

Hamilton, F., (1822). An account of the fishes found in the river Ganges and its branches. Constable Edinburgh and Hurst, Robinson and Co., London, $405 p$.

Jhingran V.G., Pullin, R.S.V. (1985). A hatchery manual for the common Chinese and Indian major carps. ICLARM studies and Reviews. 11,191-192.

Khan, R. A. (1972). Studies on the biology of some important major carps, Ph. D. Thesis, Aligarh Muslim University, Aligarh.

Khan, R. A. and Siddiqui, A. Q. (1973). Studies on the age and growth of rohu, Labeorohita (Hamilton) from a pond and rivers Ganga and Yamuna. Proc. Indian not. Sci Acad. 39, 582-597.
Kjorsvik, E., K. Hoehne-Reitan, and K. I. Reitan. (2003). Egg and larval quality criteria as predictive measures for juvenile production in turbot, Scophthalmus maximus (L.). Aquaculture. 22, 9-20.

Kjorsvik, E., Mangor-Jensen A. And Holmetjord. I., (1990). Egg Quality in Fishes. In: Blaxter, J.H.S., Southward, A.J.(Eds.), Advances In Marine Biology. 26. 71-113.

Laine, P. and Rajasilta, M. (1999). The hatching success of Baltic herring eggs and its relation to female condition. Journal of Experimental Marine Biology and Ecology. 237, 61-73.

Lowe-McConnell, R. H. (1982). Tilapias in fish communities. The biology and culture of tilapias. ICLARM, Manila, Philippines.83-113.

Mazumdar, S.R., (1957). A key to the identification of impregnated eggs of common freshwater fshes of Bengal. Curr. Sci. 26, 125-6.

Mohanta, K. N., Subramanian, S., Komarpant, N., Saurabh, S., (2008). Alternate carp species for diversification in freshwater aquaculture in India. Aqua. Asia. 13(1), 11-15.

Ochokwu, I.J., Onyia, L.U., and Ajijola, K.O. (2014). Effect of Azanza Garckeana (Goron Tula) pulp meal inclusion on growth performance of Clarias gariepinus Broodstock (Burchell, 1822). Nigeria Journal of Tropical Agriculture, vol. 14, 134-146.

Pawson, M. G., and Jennings, S. (1996). A critique of methods for stock identification in marine capture fisheries. Fisheries Research, 25, 203 217.

Quintero H.E., Durland E., Davis D.A. and Dunham R. (2011). Effect of lipid supplementation on reproductive performance of female channel catfish, 
Ictalurus punctatus, induced and stripspawned for hybridization. Aquaculture Nutrition 17, 117-129.

Rahman, A.K.A. (2005). Freshwater Fishes of Bangladesh. The Zoological Society of Bangladesh, Dhaka.p.116.

Rana, K. J. (1988). Reproductive biology and the hatchery rearing of tilapia eggs and fry. Recent advances in aquaculture, Vol. 3. Crook Helm, London, UK.3, 343-406.

Ridha, M. T. and E. M. Cruz. (1998). Observations on the seed production of the tilapia Oreochromis spilurus (Gunther) under different spawning conditions and with different sex ratios. Asian Fisheries Science
10:199-208.

Solemdal P., Makhotin V. and Fonn M. (1998). Long term studies on spawning in Arcto-Norwegian cod mortality pattern of eggs and early larvae. ICES, C.M. Doc., No. 1998/DD:8

Talwar, P. K., and Jhingran A. G. (1991). Inland fishes of India and adjacent countries. Rotterdam: AA Balkema Publishers.

Trippel E.A., Doherty C.M., Wade J. and Harmon P.R. (1998). Controlled breeding technology for haddock (Melanogrammus aeglefinus) in mated pairs. Bulletin of the Aquaculture Association of Canada, 98: 30-35.

\section{How to cite this article:}

Deepti Negi, Garima Singh, Bonika Pant and Ram, R.N. 2018. Broodstock Age as a Determinant of Embryonic Development and Growth of Rohu (Labeo rohita) under Captive Conditions. Int.J.Curr.Microbiol.App.Sci. 7(12): 2802-2812. doi: https://doi.org/10.20546/ijcmas.2018.712.318 